See Article page 128.

\section{Commentary: The heart of symptomatic neonatal Ebstein anomaly: Negative interventricular interaction and ventricular myopathy}

\author{
John D. Cleveland, MD, and Vaughn A. Starnes, MD
}

Patients with Ebstein anomaly demonstrate a wide array of clinical presentations primarily rooted in their heterogenous anatomy. Severe defects recognized on prenatal ultrasound screening and/or triggering symptoms in the neonatal period are particularly hazardous. Despite modern advances in surgical and critical care, neonatal Ebstein anomaly exhibits a perinatal mortality of $45 \% .{ }^{1}$ Knott-Craig and Bos$\operatorname{ton}^{2}$ have devoted their careers to the care of these children and contributed enormously to our understanding of the best management strategies. Their article concludes that most symptomatic neonates can undergo biventricular repair but the ideal timing for that operation is at age of 3 to 5 months. This marks an important transition away from their prior reports. ${ }^{3-7}$

Symptomatic newborn infants fall into 2 major categories: those who need time to transition from fetal life and those who are unable to survive without intervention. The number of newborn infants in each category is relatively equal. ${ }^{8}$ It has been our experience that children who are able to transition and go home have a reasonablesized true right ventricle (RV) and/or little to no tricuspid regurgitation. They do not usually develop symptoms or require surgical intervention within their first year of life.

\footnotetext{
From the Division of Cardiac Surgery, Department of Surgery, Children's Hospital Los Angeles, Los Angeles, Calif.

Disclosures: The authors reported no conflicts of interest.

The Journal policy requires editors and reviewers to disclose conflicts of interest and to decline handling or reviewing manuscripts for which they may have a conflict of interest. The editors and reviewers of this article have no conflicts of interest.

Received for publication May 31, 2021; revisions received May 31, 2021; accepted for publication June 5, 2021; available ahead of print June 10, 2021.

Address for reprints: John D. Cleveland, MD, Division of Cardiac Surgery, Department of Surgery, Children's Hospital Los Angeles, 4650 Sunset Blvd, Mailstop \#66, Los Angeles, CA 90033 (E-mail: jcleveland@chla.usc.edu).

JTCVS Techniques 2021;9:135-6

2666-2507

Copyright (c) 2021 The Author(s). Published by Elsevier Inc. on behalf of The American Association for Thoracic Surgery. This is an open access article under the CC BY-NC-ND license (http://creativecommons.org/licenses/by-nc-nd/4.0/).

https://doi.org/10.1016/j.xjtc.2021.06.012
}

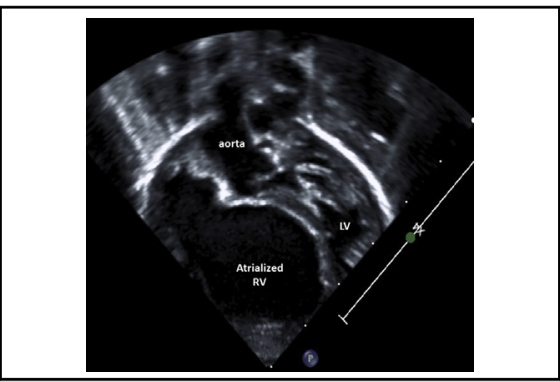

Right ventricular myopathy and left ventricular compression of a symptomatic neonate.

\section{CENTRAL MESSAGE \\ Symptomatic newborn infants with Ebstein anomaly have phys- iologic and anatomic pathology that benefit from Starnes pallia- tion when operative intervention is necessary.}

Conversely, neonates who need intervention often have tenuous pulmonary blood flow and significant right heart distension that compromises left ventricular (LV) filling and outflow via interventricular septal shift. The most appropriate intervention must secure blood flow and eliminate the cause of septal shift.

Admittedly, our group is biased. It has always been our opinion that features inherent to Ebstein anomaly favor initial Starnes palliation. The most relevant are right ventricular myopathy and failed tricuspid valve delamination. A myopathic RV is unable to effectively overcome the elevated pulmonary vascular resistance and oftunderdeveloped branch pulmonary arteries of symptomatic neonates. Secondarily, thin and attenuated valvular tissue in newborn infants makes any attempt at effective valve repair impractical. Finally, if the valvular tissue cannot be relocated to the true annulus along with a restoration of valvular competency, an atrialized RV remains at risk for distension with subsequent displacement of the interventricular septum toward the LV.

We congratulate the evolution of the management algorithm presented within this article, ${ }^{2}$ but have several critiques based on the limitations outlined above. Primarily, the presence of LV compression must be accounted for. Isolated Blalock-Taussig shunt does not address this problem. There are several areas where it is recommended, but we caution providers to consider the presence of LV compression before committing to an isolated shunt. In addition, the 
timing recommended for biventricular repair following neonatal palliation is 3 to 5 months. RV myopathy is of important concern in these newborn infants. Although rehabilitation of this ventricle is feasible for future 1.5- or 2ventricle repairs, it appears to be a process that takes longer than 3 to 5 months. ${ }^{10}$ Waiting longer may also allow for a lesser need for bidirectional Glenn. Overall, our field has come a long way since $1991,{ }^{11}$ and the future for these children has never been more optimistic.

\section{References}

1. Freud LR, Escobar-Diaz MC, Kalish BT, Komarlu R, Puchalski MD, Jaeggi ET, et al. Outcomes and predictors of perinatal mortality in fetuses with Ebstein anomaly or tricuspid valve dysplasia in the current era: a multicenter study. Circulation. 2015;132:481-9.

2. Knott-Craig CJ, Boston US. Current surgical techniques in the management of the symptomatic neonate with severe Ebstein's anomaly: too much, too little, or just enough? J Thorac Cardiovasc Surg Tech. 2021;9:128-34.

3. Knott-Craig CJ, Overholt ED, Ward KE, Razook JD. Neonatal repair of Ebstein's anomaly: indications, surgical technique, and medium-term follow-up. Ann Thorac Surg. 2000;69:1505-10.
4. Boston US, Goldberg SP, Ward KE, Overholt ED, Spentzas T, Chin TK, et al. Complete repair of Ebstein anomaly in neonates and young infants: a 16-year follow-up. J Thorac Cardiovasc Surg. 2011;141:1163-9.

5. Goldberg SP, Jones RC, Boston US, Haddad LM, Wetzel GT, Chin TK, et al. Current trends in the management of neonates with Ebstein's anomaly. World J Pediatr Congenit Heart Surg. 2011;2:554-7.

6. Knott-Craig CJ, Goldberg SP, Ballweg JA, Boston US. Surgical decision making in neonatal Ebstein's anomaly: an algorithmic approach based on 48 consecutive neonates. World J Pediatr Congenit Heart Surg. 2012;3:16-20.

7. Knott-Craig CJ, Kumar TK, Arevalo AR, Joshi VM. Surgical management of symptomatic neonates with Ebstein's anomaly: choice of operation. Cardiol Young. 2015;25:1119-23.

8. Freud LR, McElhinney DB, Kalish BT, Escobar-Diaz MC, Komarlu R, Puchalski MD, et al. Risk factors for mortality and circulatory outcome among neonates prenatally diagnosed with Ebstein anomaly or tricuspid valve dysplasia: a multicenter study. J Am Heart Assoc. 2020;9:e016684.

9. Stephens EH, Dearani JA, Qureshi MY, Ammash N, Maleszewski JJ. The congenital tricuspid valve spectrum: from Ebstein to dysplasia. World J Pediatr Congenit Heart Surg. 2020;11:783-91.

10. Da Silva JP, Viegas M, Castro-Medina M, Da Fonseca Da Silva L. The Da Silva cone operation after the Starnes procedure for Ebstein's anomaly: new surgical strategy and initial results. J Thorac Cardiovasc Surg Tech. 2020;3:281-3.

11. Starnes VA, Pitlick PT, Bernstein D, Griffin ML, Choy M, Shumway NE. Ebstein's anomaly appearing in the neonate. A new surgical approach. $J$ Thorac Cardiovasc Surg. 1991;101:1082-7. 